Georgetown University Law Center

Scholarship @ GEORGETOWN LAW

2009

\title{
The SEC and the Madoff Scandal: Three Narratives in Search of a Story
}

Donald C. Langevoort

Georgetown University Law Center, langevdc@law.georgetown.edu

This paper can be downloaded free of charge from:

https://scholarship.law.georgetown.edu/facpub/617

2009 Mich. St. L. Rev. 899-914

This open-access article is brought to you by the Georgetown Law Library. Posted with permission of the author. Follow this and additional works at: https://scholarship.law.georgetown.edu/facpub

Part of the Business Organizations Law Commons, Law and Economics Commons, and the Securities Law Commons 


\title{
THE SEC AND THE MADOFF SCANDAL: THREE NARRATIVES IN SEARCH OF A STORY
}

\author{
Donald C. Langevoort
}

2009 MICH. ST. L. REV. 899

TABLE OF CONTENTS

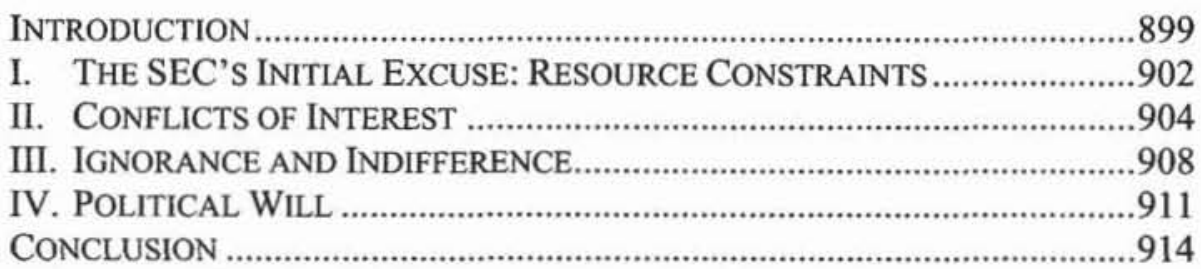

INTRODUCTION

The Bernard Madoff story, apparently the biggest investment scam in U.S. history, is fascinating non-fiction. As I write this Essay (just nine months since the scandal broke), there is no authoritative account yet, and there may never be. Journalists and authors have tried to make some sense of what happened, but with so little known for sure about the basic plot elements - the who, how, and why-interpretations still go in many different directions. The scandal is a massive human and financial tragedy, and as with all tragedies, the impulse is to find a causal story with sharply defined heroes and villains and a familiar narrative arc of temptation, hubris, and sin, followed by punishment. Madoff has confessed and been sentenced to jail for the rest of his life, but thus far revealed little. Hence the focus of sense-making has shifted for the time being to his family and business associates as possible co-conspirators, or at least enablers, along with the predictable wrangling about how much blame the victims deserve because of their extraordinary trust in Madoff and lack of skeptical diligence. The common readings run from the simplistic to the truly disturbing. ${ }^{\prime}$

* Thomas Aquinas Reynolds Professor of Law, Georgetown University Law Center. My thanks to Matt McGrath for his research help with this Essay.

1. The "Jewishness" of the fraud has been the subject of ample popular chatter, much of it distressingly anti-Semitic. Books that have already been rushed into print include ErIn ARVEdLund, Too Good to Be True: The Rise and Fall of Bernie MAdOFF (2009) (the most favorably reviewed) and JERRY OPPENHEIMER, MADOFF WITH THE MONEY (2009) (with the most predictable title). Perhaps the most intriguing journalistic coverage of Madoff thus far has been a series of articles in Vanity Fair magazine. See, e.g., Mark Seal, Madoff's World, VANITY FAIR, Apr. 2009, at 124. 
My specific subject here is the hero-villain back story involving Harry Markopolos and the SEC. Markopolos was the Boston-based financial analyst who early on came to the accurate conclusion that Madoff was probably running a Ponzi scheme, and starting around 1999 tried to convince the SEC to expose it. Although he was neither the first nor the only whistleblower, his efforts were the most detailed and persistent. ${ }^{2}$ The SEC staff did undertake a number of inspections and investigations, but never found the truth. Their main efforts were to look into the possibility of unlawful frontrunning, not the underlying legitimacy of Madoff's advisory operations. Hence the Commission missed what seems to be a relatively easy opportunity to mitigate, if not prevent, the tragic investor losses that later occurred. ${ }^{3}$

The intriguing question, of course, is why the SEC failed to detect Madoff's fraud once it was so well laid out in front of them. In this Essay, I examine three attempts at sense-making that seek to answer the question by characterizing the behavior of the staff members involved. ${ }^{4}$ Two of these came early. In January, 2009, a lengthy op-ed piece written by Michael Lewis and David Einhorn appeared in the Sunday edition of the New York Times, entitled "The End of the Financial World as We Know It." Lewis is a well-known author (Liar's Poker, Moneyball) and former Wall Street trader; Einhorn runs a well-known hedge fund. Taking on not just the Madoff scandal but a broader set of SEC failures, they amplified the criticism and alleged an insidious form of corruption inherent in the SEC's culture, whereby what happens inside the agency is largely driven by the desire of top officials to cultivate lucrative job opportunities on Wall Street when they leave. ${ }^{6}$ The SEC had no motivation to expose Madoff, they said. ${ }^{7}$ Rejecting the idea that the problem lay simply with the particular staff members involved in the fiasco, they argue that a

2. According to the Office of Inspector General Report, discussed infra, there were at least six substantive complaints raising serious concerns about the possibility of a Ponzi scheme. SEC, OfFICE OF INVESTIGATIONS, INVESTIGATION OF FAILURE OF THE SEC TO UNCOVER BERNARD MADOFF'S PONZI SCHEME, REPORT No. OIG-509 (2009), http://www.sec.gov/news/studies/2009/oig-509.pdf [hereinafter OIG REPORT]. By the time of Markopolos' most detailed presentation in 2005, the SEC had already conducted two examinations of its own. An enforcement investigation was commenced (largely at the urging of the Boston District Office) but produced nothing.

3. For a discussion of many of the warning signs, see Greg N. Gregoriou \& Francois-Serge Lhabitant, Madoff: A Riot of Red Flags (Dec. 31, 2008) (unpublished manuscript, available at $\mathrm{http}: / / \mathrm{www} . \mathrm{ss}$.com/abstract=1335639).

4. For another perspective on the SEC's failures in the last few years, including Madoff, see generally Norman S. Poser, Why the SEC Failed: Regulators Against Regulation, 3 BROOK. J. CORP. FIN. \& COM. L. 289 (2009).

5. Michael Lewis \& David Einhom, Op-Ed, The End of the Financial World as We Know It, N.Y. TIMES, Jan. 4, 2009, at WK9.

6. Id.

7. Id. 
new director of risk assessment was no more likely to grasp the risk of Bernard Madoff than the old director of risk assessment because the new guy's thoughts and beliefs were guided by the same incentives: the need to curry favor with the politically influential and the desire to keep sweet the Wall Street elite. ${ }^{8}$

Facetiously or not, they called for Harry Markopolos to be put in charge of SEC enforcement. ${ }^{9}$

Then, in early February, Markopolos himself testified before Congress and submitted a lengthy narrative that contains both his version of the effort to alert the SEC and his diagnosis of what went wrong. ${ }^{10}$ Not surprisingly, this story is also harshly critical-he's the hero and certain people at the SEC (and the SEC's own internal culture) were his antagonists, mainly via gross incompetence. He portrays them as somewhat pathetic.

Critical stories like these fed a belief that soon, in some circles, became a political cry in the midst of the financial crisis. A handful of conservatives made the claim that investor protection under the SEC was worse than having no investor protection at all, because the SEC was simply fostering the illusion of genuine regulatory effort-its own version of a con game." More moderate voices didn't go that far, but were convinced that the SEC was a severely troubled institution in need of massive reform. ${ }^{12}$

Responding to all this, the SEC's Inspector General (a relatively independent office within the agency) was instructed to investigate the "what happened" question and report publicly, which it did at the end of August $2009^{13}$ - the third narrative subject of this Essay. This document is more recitation than analysis, but interesting reading nonetheless. We discover that the staff had leads from a number of sources besides Markopolos, and actually undertook three examinations of Madoff and two enforcement investigations in response. Amidst the lengthy detail, it contains tragic-comic anecdotes of how the staff repeatedly came so close to breaking the case, but always stopped short for no good reason. Incredibly, some of those staff

8. Id. The reference to the director of risk assessment apparently refers to a conversation that Markopolos reported having with that staff member very late in his efforts to expose Madoff (early 2008), which led to a promise of follow-up but then silence.

9. Id.

10. Assessing the Madoff Ponzi Scheme and Regulatory Failures: Hearing Before the Subcomm. on Capital Markets, Insurance, and Government Sponsored Enterprises of the H. Comm. on Financial Servs., 111 th Cong. (2009) (statement of Harry Markopolos, Chartered Financial Analyst and Certified Fraud Examiner) [hereinafter Markopolos Testimony].

11. See, e.g., Assessing the Madoff Ponzi Scheme and the Need for Regulatory Reform: Hearing Before the H. Comm. on Financial Servs., 111 th Cong. (2009) (statement of Rep. Ron Paul) ("[A]ll they do is give a false sense of security."); Robert P. Murphy, The SEC Makes Wall Street More Fraudulent, Mises DAILY, Jan. 5, 2009, http://mises.org/story/3273.

12. See, e.g., Arthur Levitt Jr., How the SEC Can Prevent More Madoffs, WaLL ST. J., Jan. 5, 2009, at A13 (scandal is occasion for "fundamental reform" at SEC).

13. See OIG REPORT, supra note 2 . 
members received promotions or commendations for their work on the cases. Not surprisingly, it avoids assigning blame to the SEC's commissioners or senior executive staff: it is largely about bumbling from below.

Each of these narratives has some sort of dramatic effect, but effective narratives are not always accurate ones. The closer one gets to what passes for reality, the more ambiguity there usually is. The Lewis-Einhorn story echoes the conventional "capture" theories of regulation. ${ }^{14}$ Markopolos's and the Inspector General's accounts are more banal and mundane, if no less disturbing. The OIG Report carefully resists supporting any capture theory, but avoids thinking hard about the obvious questions about why the SEC got to the point where such incompetence could flourish except for predictable expressions of concern about lack of financial training for the staff and poor inter-office communication.

None of these three narratives quite tells the story that $I$ infer from what apparently happened. To be sure, I make no claim of inside knowledge. But the first two accounts strike me as too simple, if not simplistic, and the Inspector General's account leaves too much unsaid. So here, I want to draw a different, more sympathetic characterization. My account is more deeply about the set of forces that constrain administrative agencies like the SEC. In terms of character development in the storytelling, mine is less susceptible to stark hero-villain portrayals. There is an important difference here that speaks to regulatory capacity ${ }^{15}$ - the capture accounts are more dispositional, while mine is more situational. In the end, I am more open to the possibility of an improved regulatory regime, though far from optimistic. ${ }^{16}$

\section{THE SEC'S INITIAL EXCUSE: RESOURCE CONSTRAINTS}

Before we turn to the Markopolos and Lewis-Einhorn stories, we should consider the SEC's initial excuse (offered before its Inspector General began his investigation into what happened, and thus preliminary)that a severe lack of resources explains most of the SEC's problems. The Commission has repeatedly pointed out that its regulatory task is immense, and that budgetary growth has not kept up with either the scope or complexity of the modern financial markets. The figures commonly set forth are the numbers of regulated entities: some 12,000 public companies; 5,500 broker-

14. See, e.g., Susan E. Woodward, Regulatory Capture at the U.S. Securities and Exchange Commission, in RESTRUCTURING REGULATION AND FINANCIAL INSTITUTIONS 99 (James R. Barth et al. eds., 2000).

15. See Steven P. Croley, Regulation and Public Interests: The Possibility of GOOD REGULATORY GOVERNMENT 2 (2008).

16. See Donald C. Langevoort, The SEC, Retail Investors, and the Institutionalization of the Securities Markets, 95 VA. L. REV. 1025, 1055 (2009). 
dealer firms; 4,600 mutual funds; and 11,300 registered investment advisers. $^{17}$ This by an agency with roughly 3,500 employees $^{18}$ and a budget of under $\$ 1$ billion, ${ }^{19}$ though supplemented by self-regulatory authorities, like FINRA, and other allies.

By and large, critics have dismissed this defense, which-like most claims based on statistics-lacks dramatic force. To embellish the narrative, let me try the following. Imagine that you were brought to the top of a high mountain by a heavenly authority and asked to be in charge of securities regulation in the United States. You look out and see the array of regulatory subjects, a census of which goes well beyond those just described. Take out your telescope and notice, for example, that just one out of the 12,000 public companies is General Electric, which just by itself is of extraordinary complexity and opacity-a collective of thousands of officers, directors, employees, and affiliates. ${ }^{20}$ Imagine how much time and attention it would take to fully comprehend GE's business, operations, and financial condition. And once you are finished, there are 11,999 or so more. The 5,500 brokerage firms morph into some 670,000 stockbrokers, with some 108 million customer accounts, and include behemoths like Merrill Lynch and Goldman Sachs. We haven't even noticed the hedge funds, or the accounting profession. And through your telescope you also notice thousands of unregistered figures scurrying back and forth, perhaps up to something suspicious. And just as you begin to comprehend the immensity of what is before you, the heavenly authority mentions that the world you are looking at, way out in the far distance, has soft and permeable borders: foreign activity that easily tunnels into your world, as well as creatures from the domestic domains of banking, commodities, and insurance who pop in and out, often as undocumented aliens.

Now you're asked how much in the way of resources you would need to monitor and police this world well, fully aware of the immense profits that come to the cheaters within. Of course you'll want to think through the non-legal institutions (reputation, investor diligence) that constrain opportunism, as well as leveraging strategies that you might employ like enlisting accountants, lawyers, and bankers as gatekeepers. But especially if you are doing this in 2009 , these market-based constraints seem a little less potent

17. See Issues Raised by the Bernard L. Madoff Investment Securities Matter: Hearing Before S. Comm. on Banking, Hous. \& Urban Affairs, 11 lth Cong. 12 (2009) (statement of Linda Chatman Thomsen, Director, Division of Enforcement, SEC), available at http://banking.senate.gov/public/_files/ThomsenSECTestimony12709.pdf.

18. Id.

19. For fiscal year 2009, see SEC, PUTting InVESTORS FIRST: 2009 PERFormANCE AND ACCOUNTABILITY REPORT 15 (2009), available at http://www.sec.gov/about/secpar/secpar2009.pdf\#2009review.

20. See SEC v. Gen. Elec. Co., Accounting \& Auditing Enforcement Act Release No. 3029, Litig. Release No. 21166, 2009 WL 2398241 (Aug. 4, 2009). 
than they did a few years ago. I have no idea how much I would bargain for to take the job, but I can't imagine that it's around 3,500 people (only a portion of whom are lawyers, accountants, or economists) and a billion dollar budget. Any remotely realistic figure would probably start at many times greater than this.

I find this a fairly dramatic and telling exercise, but the SEC reduces it to a set of boring numbers, and sounds a bit whiney in the process. Why the caution? Two reasons are important. First, the SEC undermines its own authority and self-image by suggesting that it is far short of being able to do its job properly-it has always sought to project confidence to investors. The message is we need more to do our job better, but never a cry of poverty. Second, the budgetary constraint is Congress's choice, and one of the important unwritten rules of being a successful sitting regulator in an independent regulatory agency is never to blame Congress for your problems, even when Congress is very much to blame.

\section{CONFLICTS OF INTEREST}

In the public chatter and news reports surrounding the Madoff scandal, there were plenty of suggestions of conflicts of interest, such as Madoff's personal ties to regulators like chairman Arthur Levitt, ${ }^{21}$ as well as lowerlevel connections such as the fact that Madoff's niece married a former SEC attorney who-prior to the relationship, it appears-had supervisory authority in the area in which Madoff operated. ${ }^{22}$ To this point, however, there has been no credible evidence that anyone at the SEC deliberately protected Madoff. This was almost surely a sin of omission, not commission. ${ }^{23}$

As noted above, Lewis and Einhorn make a different point: that the SEC's sins came from being Wall Street's willing enablers, with the dominating motivation being senior officials' desire to preserve lucrative job opportunities at major banks and investment firms when they leave public service. "If you work for the enforcement division of the S.E.C. you probably know in the back of your mind, and in the front too, that if you maintain good relations with Wall Street you might soon be paid huge sums of money to be employed by it." ${ }^{\text {24 }}$ I suspect there is truth to the idea that an ambitious regulator would not want to alienate completely a future employer in the industry. There are now some empirical studies that document the

21. Madoff was a former board chairman of Nasdaq and served on the SEC's Advisory Committee on Market Data in 2000-01 (of which I was also a member).

22. See Elizabeth Williamson, Shana Madoff's Ties to Uncle Probed: WellRegarded Industry Figure Called "Devastated and Distraught", WALL ST. J., Dec. 22, 2008, at C3.

23. The OIG report so concludes. See OIG REPORT, supra note 2.

24. Lewis \& Einhorn, supra note 5. 
SEC's inclination to go easy on big Wall Street players in enforcement cases. ${ }^{25}$ But for a variety of reasons, I'm skeptical of precisely how far this argument can be taken. With respect to lawyers in particular, there may be some value in having been friendly to the firm (or its cohorts) in the past, but once the regulator leaves, most of the bargaining power disappears. A more fruitful strategy, as I have argued elsewhere, ${ }^{26}$ is to be a tough regulator and then exploit the specialized knowledge that comes from being involved in designing or implementing those regulations, coupled with access to the agency officials who remain behind. One could go fairly far in upsetting segments of the industry and still bring value to the future employment relationship. There are limits to this, of course: no doubt the savvy regulator understands the desirability of keeping Wall Street a vibrant, profitable, deal-generating place.

But even to this extent, how well would it explain Madoff? The disconnect in the Lewis-Einhorn story, surprisingly, is that they treat "Wall Street" as monolithic, an assembly of the economic gods that is either angry or pleased by what the regulators do. In fact, within the investment community there are nasty rivalries and dramatically differing interests, with some segments liking nothing more than aggressive regulation that hurts their competitors or counterparties more than themselves. The most potent force toward hedge fund regulation is the registered mutual fund community; broker-dealers and investment advisers have heated feuds. Madoff, for example, had many enemy rivals in the trading business who would have loved to see him disappear as an economic force. Put simply, I can't imagine that the future careers of anyone at the SEC would have been hurt by exposing him as a fraud. Quite the contrary, I suspect.

That said, I think the more general point made by Lewis and Einhorn is right-the SEC takes on Wall Street far less aggressively than it should, especially the big investment banks. But I would put the revolving-door explanation down somewhat on the list of reasons, and promote two others. One has to do with potent political influence from Congress and the White House, which we shall turn to shortly. The other takes us back to resources.

One of the SEC's lesser-known soft spots is its tendency to settle almost all its cases, which necessarily means that it leaves something of value on the negotiating table for the other side to keep. It can't afford to litigate

25. See Eric W. Zitzewitz, Prosecutorial Discretion in Mutual Fund Settlement Negotiations, 2003-7, 9 B.E. J. ECON. ANALYSIS \& POL'Y, Aug. 11, 2009, available at http://www.bpress.com/bejeap/vol9/issl/art24 (comparing penalties extracted by the SEC to the New York Attorney General's office); Stavros Gadinis, The SEC and the Financial Industry: Evidence from Enforcement Against Broker-Dealers (Aug. 11, 2009), available at http://www.ssrn.com/abstract $=1333717$.

26. See Donald C. Langevoort, The SEC as a Lawmaker: Choices About Investor Protection in the Face of Uncertainty, 84 WASH. U. L. REV. 1591, 1604, 1621 (2006). 
more than a tiny fraction of its cases. When what is targeted is a profitable bit of Wall Street opportunism, any effort to examine, understand, and respond to the phenomenon will involve a war of resources that the Commission is destined to lose unless it is willing to pull people from other needy investigations and projects and concentrate its forces. That is unappealing for many obvious reasons, and so simply on a cost-benefit calculus, we see many more skirmishes than wars, and more ambiguous armistices than victories or defeats. There just aren't enough assets to deploy.

This deprivation, I suspect, is so long-standing and pervasive that the internal SEC culture has adjusted to it, which has deep psychological effects. People cannot keep up morale if simply dwelling on the frustrations of the given task before them and the inadequacy of their resources. That is threatening to the staff's self-image, so, beliefs shift. The internal focus becomes on what is done, rather than what is ignored. Inside the SEC, one finds smart people who, by and large, work very hard with a high level of craftsmanship. They go to work on smaller, more manageable cases, ${ }^{27}$ hopefully with an attention-grabbing angle-many kinds of insider trading cases are particularly well suited for this. With people working hard on what they are doing and generating tangible results in the forms of large numbers of settlements, the anxiety diminishes. A year in which there is a twelve-percent increase in successfully closed cases becomes cause for celebration (and a round of merit pay awards), with no one really noticing anymore how woefully low the baseline figure was in the first place.

Once the culture adjusts in this way, there is no real incentive to look for big, difficult cases, with high levels of uncertainty and a massive drain on resources. That means an aversion to the more deeply disguised forms of manipulation and opportunism practiced at the higher levels in the securities business, unless evidence conveniently emerges from other sources, like the financial press or other regulators. This is not deliberate or even conscious aversion, but rather construal of situations in a way that makes it more likely that attention and resources turn to some more immediately manageable, productive task. It is human (and organizational) nature. And even the metrics become constraining. Once there is a need to have yearby-year increases in the number of cases opened, brought, and settled, the incentive to find smaller, more manageable cases becomes stronger, as does the aversion to the daunting and the costly. No one wants the SEC's equivalent of Vietnam or the Middle East wars-discouragingly massive and costly efforts that produce no readily definable victory.

In turn, this mindset also produces excessive sensitivity to the risk of failure. Though the feeling of inadequacy is masked by all the hard work

27. See Joe Nocera, S.E.C. Chased Small Fry While Big Fish, Madoff, Swam Free, N.Y. TIMES, June 27,2009 , at B1. 
and celebration of the many small victories it declares, it reveals itself in the hesitancy to bring cases to court that could embarrass the Commission-and the responsible staff-with a notable loss. That feeds both the aversion to cases whether the other side has the talent and resources to overwhelm the staff, and the culture of settling to avoid litigation risk. The fear is not of facing the consequences of winning against a powerful target, but of wasted effort and reputational damages from not being able to succeed.

Does this give us any better glimpse into the failure to expose Bernie Madoff? Imagine that you were an SEC enforcement official, confronted with the claim that Madoff must either be front-running or operating a Ponzi scheme in order to generate the steady profits that he was assuring his clients they were earning. The first reaction, of course, is that the latter seems highly unlikely-Ponzi schemes have naturally limited durations (you always eventually run out of gullible investors), so that an exit strategy is an absolute necessity. Madoff was so deeply tied to the Wall Street world-in terms of business, family, and personal wealth and commitments - that he would have no way out. Moreover, his clients were wealthy, sophisticated investors who were well positioned to do their own due diligence, making him vulnerable to a run if word spread that he was not to be trusted. There is no rational explanation for why, having built such a successful and apparently legitimate trading firm, he would ever take such a risk. $^{28}$

Without smoking-gun type evidence, this is hardly an appealing investigation to pursue. It would probably be a very costly war to wage and if your instinct is right that the likelihood of finding fraud is very low, the risks are great. Finding nothing of substance will have embarrassed and angered a powerful Wall Street figure and drained considerable resources in the process. Assume further that your investigators are already stretched thin working hard on other matters, ${ }^{29}$ and it becomes easy to put this one off. To assuage concern, you might have someone take a quick (maybe cursory) look at the front-running possibility, and when that turns up nothing, feel better about letting the matter drop.

The Inspector General's report shows precisely this kind of thinking among various mid-level staffers in New York and Washington who had a chance at the Madoff matter. One "so sad it's almost funny" discovery was that the home office-based examination team looking into Madoff concentrated on front-running rather than the Ponzi scheme possibility because

28. And if for some strange reason he did, it would probably be deeply hidden in fabricated books and records and the like that would take extraordinary effort to uncover. But it's still hard to imagine.

29. The OIG Report notes that the examiners who were working on the Madoff matter were ordered to focus instead on the mutual fund trading scandals that had just been publicized. OIG REPORT, supra note 2, at 31. 
front-running was the team's special "area of expertise" 30 - very close to the classic economists' joke about the drunk who looks for his lost car keys under the lamp post because that's where the light is the best. Ultimately, the key to breaking open the Ponzi scheme was to have sought verification via data in the possession of market counterparties, clearing agencies, etc., that the vast amount of options trading that would have been necessary for the split-strike strategy was in fact occurring-in the face of concerns, expressed by Markopolos and others, that there was no evidence of it in the usual market places. Though occasionally planned, it was never done, largely-it seems-because there was no one with the time to sift through the data dump that would have resulted. Lacking evidence, the staff was afraid. The report recounts a conversation where a senior level examiner reminded the others that Madoff was "a very well-connected, powerful person," suggesting that the staff would have to have more substantial evidence of wrongdoing in hand before pushing him hard. ${ }^{31}$

If something like that is indeed what happened, it is a very different story than one in which SEC enforcement people look the other way from evidence of misbehavior just "to keep sweet the Wall Street elite," hopes of sharing in the lucre after their departures-even if the tragic consequence is the same. The narrative loses some of its sharpness and critical bite; the portrayal of the SEC as a character shifts from villain to an institution simply lacking the capacity to become heroic, at least in this particular instance.

\section{IGNORANCE AND INDIFFERENCE}

Harry Markopolos's narrative is very different from that told by Lewis and Einhorn. It is a "bottom up" story of how he tried to convince the SEC of Madoff's fraud and the discouraging things he learned about the Commission's staff in the process. Its conclusion is more about ignorance and sloth than conflicts of interest, although he too worries some about external political pressures.

The story begins when Markopolos is asked to develop an investment product to compete with Madoff's. Doing some reverse engineering, he tries to determine how Madoff generates the low-risk, steadily healthy returns that he says he delivers to his clients every month and concludes that it is mathematically impossible using the kind of "split-strike" conversion strategy described in the promotional materials. Convinced that there must be fraud involved, Markopolos goes to the SEC's Boston District Office

30. Id. at 30. Similarly, the New York examination staff avoided looking at portfolio issues because that was "not [their] strength." Id. at 32.

31. Id. at 199, 387 (quoting Ostrow Test. Tr. 113-14; Lamore Test. Tr. 245-46).

32. See Lewis \& Einhom, supra note 5. See also notes 5-8 and accompanying text. 
(BDO), where he is first rebuffed. But eventually, he finds a financial analyst on the staff who, he says, understands and agrees an investigation ought be launched. Others in the BDO seem to concur. However, that office does not have jurisdiction over Madoff - the Northeast Regional Office (NERO), based in New York, does. In his version, he is left to start anew at the NERO fairly much on his own, which he does in 2005. There he hits what appears to be a brick wall, mainly in the person of Meaghan Cheung, a branch chief, who seems to show no interest in what he is saying. To Markopolos, this is mainly because Cheung lacked the basic financial and mathematical knowledge to understand him or the problem. She just didn't get it.

There probably is more color to the encounter than that. To say the least, Markopolos comes across as a strange protagonist even in his own narrative. He fills his account with repeated references to his background in military intelligence, fear for his life, and the need for hyper-security in the dangerous mission his group had undertaken. ${ }^{33}$ His interpersonal skills don't seem to be the greatest. He makes plain to Cheung that he thinks she and everyone else at the SEC are lacking in the financial sophistication to crack this case. Thus they need him-Markopolos-as a key player on the investigatory team. ${ }^{34}$ When told that the staff has $\mathrm{PhD}$ economists they could consult instead, he remarks that they can't be worth anything because the Commission doesn't pay enough to attract the truly qualified. ${ }^{35}$ This is not how to win friends and influence people.

I suspect (and the Inspector General's report concurs) that Cheung quickly made the judgment that Markopolos was obnoxious and selfabsorbed, deep into his own personal crusade against Bernie Madoff, which caused her not to pay as much attention to the underlying argument as she should have. The SEC gets tens of thousands of purported whistle-blower "tips" each year, and many are from people whose motives are not very public-spirited. Tips from competitors are particularly problematic. Here, I suspect that she may have started employing the heuristics mentioned earlier: Madoff would have to be crazy to pull a stunt like this given his deep ties to both Wall Street and Washington, and his sophisticated clientele were not the type to easily be fooled by a big lie. She was horribly wrong, of course, but I suspect that many of us would have had the same reaction.

33. Markopolos Testimony, supra note 10, at 1, 3, 4, 25, 49 .

34. Id. at 17 ("When I mentioned that my derivatives expertise would be needed to break the case open, she dismissed me .... In my experience, once a case is turned into the SEC, the SEC claims ownership of it and will no longer involve the investigator. The SEC never called me.").

35. Id. at 16 (telling Cheung that "a true derivatives expert couldn't afford to work for SEC pay"). According to the OIG report, the staff did at one point seek the aid of the SEC's economists, but did not get useful help. OIG REPORT, supra note 2, at 18 . 
I'm sure it affected the depth and vigor of the investigation that was later undertaken by the NERO.

Shed of the personal obsession, Markopolos's story comes across as fairly mundane: he sees Cheung and the others as petty bureaucrats-not up to the challenges of their regulatory domain, more bumbling than villainous. What's more, her task had its own obstacles. Unbeknownst to Markopolos, two SEC examination staffs had investigated Madoff during the prior two years - though not well, obviously - and the New York-based team lobbied against any effort to reopen the case and risk being proven wrong. ${ }^{36}$ And the junior staff member working for Cheung on the case was relatively new to the Commission, just a year and a half out of law school, and completely new to broker-dealer matters.

Markopolos's diagnosis calls mostly for a thorough housecleaning. Use fewer lawyers, and hire investigators with financial training and industry experience instead. Promote greater continuing financial education. Put in place bonus plans tied to the amount of fines collected by the branch or office involved. Focus on enforcing ethical principles, not legal rules. (Further on he says that if this proves impossible, the federal government should simply delegate its securities enforcement work to the New York Attorney General's Office and the Massachusetts Securities Division..$^{37}$ )

This Essay is not about regulatory reform, and so this is not the place to go into the merits of these particular proposals. I do agree fully with his criticism of excessive reliance on lawyers at the SEC and the need to introduce far greater financial sophistication into the agency's thinking and training. In many ways, the SEC needs to turn itself into a "Financial Intelligence Agency" that uses more effective "on the ground" surveillance tools to understand and monitor emerging risks to investors in the financial markets and securities industry.

In fact, all this seems so obvious that the only interesting point is why it didn't happen long ago. Go back to the mountaintop I described earlier and consider what resources you'd bargain for before agreeing to oversee the world of securities. Just a little thought would lead you to demand dedicated, sophisticated surveillance personnel, both for investigations and regulatory policy. Continuing education-with strong connections to business schools and economics programs, not just law schools and the legal profession-would be a priority, too.

Their absence, I suspect, is mainly just another manifestation of the relative poverty of the SEC. To be sure, the lawyer domination of the agency has led to an excessive marginalization of economics and finance at

36. See OIG REPORT, supra note 2, at 257 (describing the cultural issue of examiners trying to discourage any reopening of matters that might cast doubt on their competence).

37. Markopolos Testimony, supra note 10, at 49-50. 
times, and that hegemony is self-replicating. Professional managerial skills are in short supply. But even that is in an environment of competition for scarce resources-in a world of plenty, even lawyers would be happy to spend money having their subordinates learn more finance and hiring skilled expert assistance for the more technical, challenging tasks. And so we are back to a question that gets relatively little attention from Markopolos, Lewis and Einhorn, or the Inspector General: what explains that historic poverty?

\section{POLITICAL WILL}

The portrayals of the SEC as either utterly conflicted or cluelessly inept are overdrawn. Much of the work the SEC actually does in the enforcement and inspection area is done competently. The failures are largely in what is ignored or missed, like Madoff, and the relative poverty of the agency in light of its assigned mission - and the protective culture that has emerged inside the agency to blunt the frustrating reality-are better explanations, but lack narrative spark.

What is left is to ask why the impoverishment persists. As has long been pointed out, the SEC takes in more in fees imposed on various securities-related activity than it costs to operate the agency, and the fees are very low. Congress could easily increase the agency's budget simply by increasing the fees. The SEC also produces large sums via civil penalties and disgorgement, none of which it keeps.

Of course, the SEC is hardly the only budgetary priority for the nation, and any sums collected in fees and penalties that are redirected to the SEC are sums that can no longer support other important programs. The budgetary issue and SEC self-funding are complex and difficult issues. Nor can we assume that a major budgetary increase would be entirely well spent. The SEC is a bureaucracy with fairly weak internal incentives, and it would take strong, sophisticated leadership to cause new resources to fill the most pressing gaps efficiently, rather than support old habits of avoidance. Overregulation is also an inevitable risk.

That points to one possibility, that under-funding was part of a more pervasive belief in the power of markets to cleanse themselves, and of nonlegal forces like reputation, competition, and learning from experience to substitute for aggressive legal intervention. Indeed, some have claimed that the SEC's recent failures-including Madoff-are at least partly the product of a government-wide anti-regulatory philosophy over the last decade or so. ${ }^{38}$ One criticized example, relevant to Madoff, is the belief that sophisticated, wealthy investors can fend for themselves and don't need the SEC's

38. See Poser, supra note 4, at 317-19. 
help. Such a belief, of course, might explain the SEC's relative disinterest in Markopolos's tip.

It is not clear, however, that there was ever any strong ideological opposition to serious antifraud enforcement with respect to cases like Madoff's $^{39}$ The Commission has brought a number of enforcement actions where the wealthy were victimized, including some involving institutional investors as victims. What is likely, however, is that in doing triage, the Commission does place a higher value on cases targeting retail investors, and assigns those against the wealthy a somewhat lower priority-once again, a resource-based account.

My sense is that the relative poverty of the SEC goes back much longer than the last decade, ${ }^{40}$ and reflects something more engrained in the political process. Congress maintains increasingly tight control over SEC policy largely through the budgetary process, and having the Commission be habitually needy and under-resourced fits well within this strategy. The cam-

39. I do think, however, that such beliefs can have an effect on internal morale and motivation, which in turn influences all behaviors. See Langevoort, supra note 26, at 1624. There was a troubling disagreement between the commissioners and the enforcement staff about pre-approvals for settlements, which has since been resolved. But this apparently grew out of concern that the staff was too aggressive in one area-massive fines against companies, as opposed to sanctions against individual wrongdoers. The commissioners' concern was that these fines essentially penalize the issuer's shareholders, who are supposed to be the beneficiaries of the SEC's work. Without getting into this difficult subject area, which I have written about at length elsewhere (see Donald C. Langevoort, On Leaving Corporate Executives "Naked, Homeless and Without Wheels": Corporate Fraud, Equitable Remedies, and the Debate Over Entity Versus Individual Liability, 42 WAKE FOREST L. REV. 627 (2007)), I think there is substance to that concern, though Cox overreacted in terms of process and thereby sent an unfortunate signal of mistrust. The staff's inclination that close cases with a well-publicized sanction can too often lead to shifting responsibility away from the individuals who bear the most blame-insiders are happy to approve a settlement when little or nothing comes out of their own pockets-and placing the burden on shareholders. But this unfortunate intramural squabble was about policy, not ideology. This aside, the SEC's enforcement program changed very little from the 1990 's to the present in terms of types of cases brought or the allocation of investigatory resources, and Cox's enforcement director, Linda Chatman Thomsen, was an able veteran of prior administrations.

40. A troubling-perhaps embellished-account by the founder of the Stratton Oakmont brokerage firm tells how he and his lawyer (Ira Sorkin, who also happened to be Madoff's lawyer) easily outmaneuvered the SEC, which is portrayed as somewhat bumbling and overly cautious. This occurred in the mid-1990s. See JORDAN BELFORT, THE WOLF OF WALL StreEt 227-35 (2007). Belfort quotes Sorkin as doubting the Commission's will to pursue a tough case as far as they should, and Sorkin supposedly offers career-based reasons for their excessive caution. Id. But it is mainly reputational fear about bringing a case and losing it. If we go back another decade - to the Reagan and first Bush Administrations, we see substantial praise for the aggressiveness of the Enforcement Division, at least as applied to its pursuit of insider trading on Wall Street. See generally DAVID A. VISE \& STEVE COLL, EAGLE ON THE STREET (1991). Of course, these "non-fiction" accounts may well miss deeper truths. The insider trading campaign in the mid-1980s targeted high-profile Wall Street players, for example, but ones who also had many enemies in the business community. 
paign contributions from various sources with an interest in securities regulation are large, and influential members of Congress hardly maximize their own political advantage by stepping aside and leaving the SEC free to do its work as it sees fit. Maybe there was more freedom decades ago, when powerful legislators defended the SEC because its work mirrored what they and their constituents wanted fairly closely. Today, however, that populist legacy has disappeared, and Congress wants implicit control over the key issues. The SEC suffers when it gets out of line.

That explains a great deal. If we assume that corporate issuers and the financial services industry together wield the most clout, a relatively impoverished SEC inspection and enforcement program is a likely equilibrium outcome. Not so impoverished that it becomes entirely meaningless, because that is not in the business community's interest. Fraud not only hurts investor victims, but competitors as well. Moreover, investors will shy away from investing when there is the perception that no one is looking after their interests.

But the desired political equilibrium is one where the SEC doesn't have the luxury of deep surveillance into the financial world either, and has to tread cautiously before undertaking any major battles. That is precisely what we have. And the result is that cases like Madoff can recur, for all the reasons suggested earlier. It is not because Wall Street wants to protect someone like Bernie Madoff, but because the abundance of tools and resources that might make that more likely to happen can too easily be put to use to threaten more sensitive interests.

Harry Markopolos and many other SEC critics have compared the Commission's failures to the successes of the Attorney General's offices in New York and Massachusetts, to show what a good enforcement shop should look like. Without going into a detailed comparison (and putting aside that New York didn't stop Madoff either), note two crucial differences. One is that, unlike the SEC, these state authorities have criminal sanctions at hand, which is particularly important given the collateral consequences for a securities firm of either indictment or conviction, even of a misdemeanor. That threat gives state Attorneys General much greater bargaining power. Though some at the SEC have wished otherwise, Congress has carefully limited the SEC to civil enforcement. Second, these Attorneys General are elected officials with independent power bases and political ambitions that are advanced by high-profile actions. They do not work for their legislatures in the same way the SEC works for Congress. Without altering the subservient political structure of the relationship between the SEC and Congress-which will not happen-the comparison is fruitless. ${ }^{41}$

41. For a more critical perspective, see Jonathan R. Macey, Wall Street in Turmoil: State-Federal Relations Post-Eliot Spitzer, 70 BrooK. L. REv. 117 (2004). 
[Vol. 2009:899

\section{CONCLUSION}

The SEC's failure to catch Bernie Madoff is a sad and important story, but not one easily told. Images of an agency either riddled by ineptitude or acting as Wall Street's captive enabler don't describe the much more complicated reality. Neither, however, is the SEC's self-conception as the investors' champion-fed by the ample amount of good work that it does accomplish every day-which too easily blinds believers to all the other work that could be done but is not, and all the troubling places in our securities markets that still operate in the dark. ${ }^{42}$

Meghan Cheung and the others at the SEC should have thought deeper and harder about the risk Harry Markopolos described-with the benefit of hindsight, they admit as much. But the institutional setting in which they work, with demands that far exceed either capacity or resources and a resulting culture that rewards taking paths of least resistance, makes it likely that many of us would probably have done the same thing. ${ }^{43}$ Working under burnout conditions that make it impossible to do as well as one wants (or the outside world expects) is demoralizing. The SEC is a proud old agency with enough myths and internal routines to deflect some of that doubt, but the result is still too many staff-level decisions that give in to the limits of the job. The task is to imagine the counterfactual ideal of securities regulation done with adequate resources, knowledge, and political independence. ${ }^{44}$ The deeper story about the SEC and Bernie Madoff, far too complicated to be a compelling popular narrative, is why we are where we are rather than in that much better regulatory world.

42. See Langevoort, supra note 26, at 1611-12. Perhaps this is a form of "deep capture." Cf. Jon Hanson \& David Yosifon, The Situation: An Introduction to the Situational Character, Critical Realism, Power Economics, and Deep Capture, 152 U. PA. L. REV. 129 (2003) (describing the cognitive component of deep capture). For a claim of deep capture by financial elites, see Simon Johnson, The Quiet Coup, ATLANTIC MONTHLY, May 2009, at 46.

43. Cheung and others involved were clear in expressing frustration with the poor resources and excessive demands of their jobs. See OIG REPORT, supra note 2, at 364-66.

44. To be sure, this would not necessarily be an ideal world, if the additional resources were turned into regulatory excess. 